\title{
LAND TENURE OF SMALL ISLANDS AND COASTAL AREAS IN ECONOMIC AND DEFENSE ASPECTS
}

\author{
I Made Pria DHARSANA (i) $1 *$ \\ Indrasari KRESNADJAJA (iD) 2 \\ I Gusti Agung JORDIKA PRAMANDITYA (iD ${ }^{3}$ \\ 1 Warmadewa University, Faculty of Law, imadepridharsana@gmail.com *Correspondent Author. \\ 2 Warmadewa University, Faculty of Law, indrasari_kresnadjaja@outlook.com \\ 3 Warmadewa University, Faculty of Law, jordikasih@yahoo.com
}

\author{
Article history: \\ Submission 12 March 2021 \\ Revision 09 May 2021 \\ Accepted 04 August 2021 \\ Available online 31 August 2021
}

\section{Keywords: \\ Tenure, \\ Coastal Areas, \\ Economic Aspects, \\ Land Aspect.}

DOI:

https://doi.org/10.32936/pssj.v5i2.220

\begin{abstract}
A b s t r a c t
The question of the purpose of statehood hovers again to collect the pledges of the development actors. The goal to become a nation-state that provides a place and humane and proper way of life is still harassing residents of coastal areas and small islands as part of the natural resources bestowed by The One Almighty God to the Indonesian people. Coastal areas and outer small islands are national assets controlled by the state and need to be preserved and utilized as much as possible for the prosperity of the people, both for present and future generations and for the interests of defense and security. related to the threat of remote island tenure which by certain elements were transferred to the land tenure rights that should belong to the village customary land, but there was a process of transferring rights which were then held by foreigners with the argument related to economic issues that were less supportive in the area by nominee or by road rent that threatens the stability of national defense.
\end{abstract}

\section{Introduction}

Concentration of Indonesian population with more than $60 \%$ living in coastal areas (Subagiyo, et al 2017). As part of natural resources, coastal areas and small islands have enormous and strategic potential for social, cultural, economic, environmental (ecological) development and support for national sovereignty. Several regions in Indonesia which geographically have coastal areas and small islands realize the importance of managing these areas for various activities both economic and conservation in a balanced and appropriate manner (Chikmawati, 2020). The national wealth has been ordained in the 1945 Constitution of the State of the Republic of Indonesia to be used for the greatest achievement for the prosperity of the people. Article 33 (3) of the 1945 Constitution affirms that "Earth, water and natural resources contained therein are controlled by the State and used for the greatest prosperity of the people". The conception of the right to control the state in relation to natural resources (land) as stipulated in the 1945 Constitution is reaffirmed in Law no. 5 of 1960 concerning Basic Regulations on Agrarian Principles (better known as UUPA). The UUPA is based on the stance that in order to achieve what is stipulated in Article 33 paragraph (3) of the 1945 Constitution, it is neither necessary nor appropriate, the State acts as the owner of the land.

Exactly, if the State as an organization of power all the people act as the governing body. On that basis, Article 2 paragraph (1) of the UUPA stipulates that "Earth, water, and space, including the natural resources contained therein, are at the highest level controlled by the State as an organization for the wealth of all the people". In this context, the relationship between the State and the earth, water and space and the natural resources contained therein is a relationship of control, not a relationship of ownership.

And it is a wise action for the government if it carries out its function to regulate the order, especially in this issue of coastal and small islands. However, these arrangements must not conflict with the interests of the management of the coastal environment and the community, especially traditional fishermen. The regulation as intended should also not conflict with local wisdom. For example, along the coasts of the islands of Java, Sumatra, 
Kalimantan, West Nusa Tenggara and Papua, for example, until now, various local cultures and traditions are still alive (continuing to grow and develop). And the Indonesian constitution really appreciates the existence of these cultures. Therefore, Indonesia as a state of law, where the constitution is the philosophical basis of national law, then the existing rules should not conflict with the constitution. Because the constitution is the basic law that is used as a guide in the administration of a country. The constitution is the supreme law of the land, where it becomes the spirit for the provisions of the legislation under it. Thus, every statutory regulation that is contrary to the content and spirit of a constitution must be declared to have no binding force. The conception of the relationship between the State and natural resources departs from the assumption that the State is a subject in the sense of personification of all Indonesian people, not as individuals or state bodies. In this conception, the state cannot be separated from its people, so the rights of the state are community rights or imperial rights, namely the right to control land or its use.

Thus, the relationship between the State and land in the concept of State Controlling Rights is a relationship that gives authority to the State as an organization of power for all Indonesian people, at the highest level (Himanto, 2017):

(1). Regulate and administer the designation, use, supply and maintenance of earth, water and space;

(2). Define and regulate the legal relationships between people and the earth, water and space;

(3). Determine and regulate legal relations between people and legal actions concerning earth, water and space.

The contents of the state's authority are solely public, namely the authority to regulate and not the authority to physically control the land and use the land as the authority of the holder of private land rights.

The authentic interpretation of the State's Right to Control as referred to by the 1945 Constitution, is a purely public relationship. Thus, there will be no other interpretation regarding the interpretation mastered in the article of the Constitution. Meanwhile, the term "private" refers to the authority of the right holder to use the land in question for his interests and to fulfill his personal and family needs. This is emphasized in Article 9 paragraph (2) of the UUPA which states that: "Every Indonesian citizen, both male and female, has the same opportunity to obtain a land right and to obtain the benefits and results, both for themselves and for their own benefit. himself and his family".
From the word transformed "Coastal Areas or Small Islands" There resides prayers and pujas to get the maximum benefits and results for the prosperity of the resident community, it is different for the islands to be uninhabited. But does the government really care about that? The words "to get benefits and results, both for themselves and their families" indicate the personal nature of land rights in the conception of the National Land Law. The state's authority to regulate legal relations between people, including customary law communities and land, is closely related to the legal relationship between the state and land. This is because the legal relationship between the state and land greatly influences and determines the content of laws and regulations governing the legal relationship between people and land and customary law communities and their customary lands, as well as the recognition and protection of rights arising from these relations. the legal relationship. Currently, the regulation is only limited to land management policies in coastal areas and small islands, but it has not been spelled out in the form of legislation. This means that land arrangements on small islands are generally still subject to the UUPA and its implementing regulations related to the granting of land rights. Institutionally, indications of land regulation specifically in small islands can also be seen in the Presidential Regulation of the Republic of Indonesia Number 10 of 2006 concerning the Organizational Structure of the National Land Agency. Within this structure, there is one directorate that specifically handles small islands, namely the Directorate of Coastal Areas, Small Islands, Borders and Certain Areas which is under the Deputy for Land Regulation and Arrangement. The existence of the Directorate of Coastal Areas, Small Islands, Borders and Certain Areas is based on the consideration that in general the land is managed in general, but there are certain areas that must be managed specifically, such as coastal areas, small islands, certain areas, because it has certain characteristics.

In addition to the regulations in the land sector mentioned above, Law no. 27 of 2007 concerning the Management of Coastal Areas and Small Islands as a reference in the management of coastal areas and small islands specifically. All of the legal references mentioned above should be used as a reference in regulating the control and ownership of land in coastal areas and small islands, because in my view, land in coastal areas and small islands should not be considered the same as land on ordinary land (mainland), because of the peculiarities possessed by the region.

For this reason, it is necessary to immediately realize legal arrangements for ownership and control of land as an ecosystem unit with the surrounding waters, in the form of separate laws and regulations by taking into account the economic, political, sociocultural, environmental and defense and security aspects in an integrated manner. 
Based on the description above, this research aims to find out how the control of land by the surrounding population living in small islands and coastal areas is reviewed through economic and defense aspects, and to find out how the legal consequences for the control of the land of the smallest islands and coastal areas by people foreigner through a lease agreement or other form of agreement.

\section{Research Method}

the rules and laws that apply to answer the legal problems studied (Efendi and Ibrahim, 2016). The research approach uses a philosophical approach, a statutory approach, an analytical approach, a conceptual approach, a case approach and a comparative approach. The sources of legal materials used consist of primary legal materials, secondary legal materials, tertiary legal materials or non-legal materials. Primary legal materials consist of statutory regulations; secondary legal materials consist of all publications on law that are not official documents such as scientific journals. Tertiary legal materials consist of encyclopedias and legal dictionaries. The technique of collecting legal materials is done by literature study. The technique of analyzing legal materials is carried out through several stages, namely (Diantha, 2015):

descriptive technique, namely by describing the legal conditions regarding land tenure

- comparative technique, namely by analyzing secondary legal material in which there are various views of legal experts as a "dialectical layer" both pros and cons. Then it is crystallized to produce a provisional truth for the researcher's argument.

evaluative technique to determine the legal conditions associated with pro and contra opinions.

argumentative techniques to provide reasoning or reasoning or explanations that make sense in order to answer research problems.

\section{Results and Discussion}

\subsection{Harmonization of Law on Land Tenure and}

\section{Ownership of Coastal Areas and Small Islands}

Coastal resources and small islands are one of the important resources for people's livelihoods and can be used as the main driver of the national economy. This is based on the fact that first, Indonesia has a high potential of coastal resources and small islands with the characteristics of various coastal areas and small islands. Second, most of the industrial activities in regencies/cities are located in coastal areas. Third, industrial activities in coastal areas have strong backward and forward linkages with other industries. Fourth, coastal areas and small islands are a local resource base for the fishing industry or known as resources-based industries and Fifth, coastal areas in Indonesia have a high comparative advantage as reflected in their potential fish resources (Elysa, 2014).

The limited space for community participation in resource management for coastal areas and small islands shows that the principles of integrated coastal and small island management have not been integrated with development activities from various sectors and regions. Norms for the Management of Coastal Areas and Small Islands that will be published are focused on legal norms that have not been regulated in the existing statutory system or are more specific than the general regulations that have been promulgated. The norms are expected to give roles to the Government, the community, and the private sector as stakeholders, both regional interests, national interests, and international interests through an integrated area management system. In accordance with the nature of the Unitary State of the Republic of Indonesia as a state of law, the development of a system for the Management of Coastal Zone and Small Islands as part of sustainable development with an environmental perspective must be given a clear, firm and comprehensive legal basis to ensure legal certainty for efforts to manage the Coastal Zone and Small Islands. The legal basis is based on Pancasila and the 1945 Constitution of the Republic of Indonesia.

Indonesia needs a strategy to achieve its goal as the world's maritime axis. One that can be offered is to increase coastal resources and small islands. Management of coastal resources and small islands is the duty of the community (Ulisyah, 2017). Planning, utilization, Supervision and Control of Coastal Zone and Small Islands still encounter many obstacles and must be synergized with the provisions of Law Number 23 of 2014 concerning Regional Government. This situation illustrates that there are still many obstacles and obstacles in terms of Management of Coastal Areas and Small Islands. The results of research and academic studies of the DPR RI, for example, state that understanding and limitations regarding general provisions, both "fishermen" and "coastal communities" must be a concern and findings of field data input. In the general provisions (Chapter I) of Law Number 27 of 2007 concerning Management of Coastal Areas and Small Islands (PWP3K), as amended by Law Number 1 of 2014, it is stated that the definition and limitations referred to in the PWP3K Law.

Of the 44 definitions, it does not specifically (explicitly) mention the definition or limitation of "fishermen", who are actually part of the coastal community. Likewise, the definition of "coastal communities" is not specifically mentioned in the general provisions. The PWP3K Law, in fact, emphasizes "coastal area 
management" as its spatial management. However, it is certainly related to coastal communities, as indigenous peoples, local communities and traditional communities who live (settle) and have activities in coastal areas. Coastal areas are clearly defined in the PWP3K Law, are transitional areas between land and sea ecosystems that are affected by changes on land and at sea. This emphasizes the spatial spatial of terrestrial and marine ecosystems. Meanwhile, "communities" related to coastal areas are defined as communities consisting of Indigenous Peoples, Local Communities and Traditional Communities who live in coastal areas and small islands. The findings of observers of the implementation of the PWP3K Law in various regions who discussed with Indonesian Fishermen Association (HNSI), Maritime Partners and non-governmental organization (NGOs) (both in South Sulawesi, North Sumatra, and DI Jogjakarta), emphasized that the lives of fishermen as a weak community group need to be considered and empowered. This law should be in favor of fishermen's lives, as traditional communities and coastal communities.

Based on the results of the study, analysis and evaluation of the implementation of Law Number 27 of 2007 concerning PWP3K as amended by Law Number 1 of 2014 has been carried out by the Center for Monitoring the Implementation of the Law on Expertise Board of the Republic of Indonesia. There are several basic things as a formulation of norms contained in the said law, which give rise to multiple interpretations which could potentially not be implemented properly. The occurrence of overlapping rules and various interpretations of all stakeholders, consequently causing a commotion in terms of control and use of land in coastal areas and small islands, which have a direct impact on the community and the resources themselves. There is a tendency to use positive laws governing the area to be used to smooth out the interests of certain groups in the control and utilization of natural resources. In such conditions, the role of the Central Government and Regional Governments is urgently needed to become a judicial judge in order to function the law in order to provide certainty and protection to all parties, both individuals, communities, private sector and the government itself.

According to Roescoe Pound in Fuadi (2013), the existing law must be able to function as a tool of social engineering and an instrument of community renewal (agent of change). The presence of law should be able to guide the government and its people towards what they aspire to. A good law is a law that can be accepted by the community without enforcement efforts (coercion) but a necessity. In relation to this legal function, the legislators, through interpreting the meaning of Article 33 paragraph (3) and paragraph (4) of the 1945 Constitution, have laid the juridical foundation and intergenerational justice. To realize justice between generations, the government must put itself in a neutral position. For the sake of creating something that is created in the form of a legal product that is desired by the community and the course of a positive legal rule, what is needed is in the form of legal goodness while according to Leawoas and Radbruch (2000), legal goodness is defined into 3 types of legal subjects. The two Laws which were drawn up with that aim resulted in a collective legal system; not individual or collective human, but includes culture. According to W. Friedman (1975), harmonization of rules and their implementation will never be realized if the government as the regulator does not place itself as a provider and in a neutral position. In addition, it is necessary to apply the principle of social justice in the sense of prioritizing interests that have an impact on welfare for most levels of society, compared to mere exploitation interests which only have an impact on the interests of certain individuals and groups (Rasjidi and Rasjidi (2007).

Management of coastal areas cannot be separated from the status of the function and ownership of land in the area. The granting of land rights, whether individually controlled or traditionally controlled for land areas that are not affected by the tides, is easier to complete, because it has been regulated by the UUPA and other laws and regulations (Arisaputra, 2015). The management of coastal areas and small islands so far has put more emphasis on the economic aspect, resulting in a tendency for massive exploitation that has an impact on environmental aspects and the social order of the people. A legal instrument in the use of coastal waters and small islands as regulated by Law no. 27 of 2007 concerning the Management of Coastal Areas and Small Islands which are considered by the legislators to be able to become a strong basis for their use, namely the right instrument in the form of HP-3 (Coastal Waters Concession Rights). The constitutional basis for the control and ownership of the land mentioned above is to provide signs in the regulation of land control and ownership, including the control and ownership of land in coastal areas and small islands. However, because coastal areas and small islands have distinctive characteristics and are different from the mainland, such as being vulnerable to environmental changes, which are also a buffer zone for national sovereignty, the regulation of land tenure and ownership should also take into account these distinctive characteristics. In addition, it must pay attention to the aspect of the coastal border as a protected area and regulation of public access. The coastal border is land along the edge whose width is proportional to the shape and physical condition of the beach at least 100 (one hundred) meters from the highest tide point towards the land. The determination of coastal boundaries is carried out by the Regional Government by adjusting the characteristics of topography, biophysics, coastal 
hydro-aerography, economic and cultural needs and other provisions.

The tendency to regulate land tenure and ownership in coastal areas and small islands in particular can be seen in the development of regulations related to it. Government Regulation No. 40 of 1996 concerning Cultivation Rights, Building Use Rights and Land Use Rights, Article 60 stipulates, that: "The granting of Cultivation Rights, Building Use Rights and Use Rights on a piece of Land which is entirely an island or bordering the coast is regulated separately by Government regulations".

This explanation of Article 60 confirms that with this provision, requests for new land rights which are entirely islands and bordering the coast will not be served until the issuance of the said Government Regulation. However, if referring to the provisions of Article 62 of Government Regulation (PP) Number 40 of 1996, land rights for small islands may be granted certain land rights, but with strict conditions. As long as the government regulations referred to in Article 60 have not been issued, the laws and regulations regarding Cutivation Right (HGU), Building Right (HGB), and Usufructuary Right (HP) remain valid as long as they do not conflict with the provisions in government regulations. The Minister of State for Agrarian Affairs/Head of the National Land Agency of the Republic of Indonesia gave directions for the implementation of the Government Regulation in Circular Letter Number 500-1197, dated June 3, 1997, which was later reaffirmed by Circular Letter Number 500-1698, dated July 14, 1997, which was addressed to the Head of the Office of the Republic of Indonesia.

The consideration of the issuance of the Circular Letter is because of the large number of applications submitted to obtain land rights which are entirely islands or those bordering the coast, while the provisions of Article 60 and its explanation expressly state that applications for land rights which are entirely islands should not be served until the issuance of this regulation. The Circular Letter is the reference for the Head of the Regional Office of the Provincial National Land Agency and the Head of the Regency/City Land Office in responding to requests for land rights on small islands, because there have been no government regulations issued relating to land regulations in coastal areas and small island.

A legal instrument in the use of coastal waters and small islands as regulated by Law no. 27 of 2007 concerning the Management of Coastal Areas and Small Islands which are considered by the legislators to be able to become a strong basis for their use, namely the right instrument in the form of HP-3 (Coastal Waters Concession Rights). However, the HP-3 has been revoked by the
Constitutional Court in the Decision of the Constitutional Court Number 3/PUU-VIII/2010 which was pronounced on Thursday, June 9, 2010 in the Plenary Session of the Constitutional Court (MK) open to the public. The Constitutional Court's decision has stated that it has no binding force on 14 articles related to HP-3. All provisions relating to HP3 in those articles were considered by the Court to be contrary to the 1945 Constitution. The main issue that the Court considered was the constitutionality of the articles which were deemed to be contrary to the 12 (twelve) constitutional norms in the 1945 Constitution. The Court was of the opinion that the use of the Territory Coastal and Small Islands with HP-3 instruments cannot guarantee the greatest prosperity of the people.

There are 4 (four) benchmarks used by the Constitutional Court in measuring the benefits for the greatest prosperity of the people, namely (Ranto, 2017);

(a) utilization of natural resources for the people;

(b) the level of equitable distribution of the benefits of natural resources for the people;

(c) the level of people's participation in determining the benefits of natural resources;

(d) respect for the rights of the people from generation to generation in utilizing natural resources. These four benchmarks are used by the Constitutional Court to judge HP- 3 as against the Constitution.

In its legal considerations, among others, affirming that, the Constitutional Court assessed that although there are guarantees in Article 61 of the Coastal Law for the recognition, respect and protection of the rights of indigenous peoples over coastal areas and small islands that have been used for generations, the rights of The customary law community have the potential to be handed over to the private sector by providing compensation in the form of HP-3. In addition, the provision of HP-3 is a form of legalization of the division of coastal areas and small islands to be used as private ownership and close ownership to individuals, legal entities or certain communities. It is even more ironic that the placement of HP-3 as Property Rights is assessed by the Constitutional Court to result in the transfer of ownership and control by the state in the form of single ownership and close ownership to individuals, community groups and legal entities so that it will close access for everyone to the area given by HP-3. Giving HP-3 violates the principle of economic democracy based on togetherness and the principle of justice.

The principle of togetherness must be interpreted that in the implementation of the economy it must involve the people as widely as possible and be profitable for the welfare of the people. 
HP-3 is considered to only benefit owners of large capital. Therefore, to avoid the transfer of responsibility for state control over the management of coastal waters and small islands to the private sector, the state can grant the right to make the Constitutional Court's decision, in fact, affirming two things (Waluyo, 2013);

First, that the utilization of coastal areas and small islands must be carried out through a licensing mechanism from the government and local governments. However, for indigenous peoples or local communities who have lived in the area for generations, they must be given a strengthening of their position in the form of rights.

Second, the use of coastal areas and small islands must be in the interests of the people as a whole, not only for the interests of individuals or certain groups or only owners of capital, by ignoring the constitutional rights of the people to obtain prosperity for monitoring the resources of coastal areas and small islands. Thus, there is a need for balance and harmonization between positive law and the law that lives in society as a guide in carrying out legal actions.

For this reason, referring to the legal system adopted in Indonesia, the presence of positive law is still needed to provide legal certainty, but its incarnation must be in the absorption of natural law that is integrated into the positive law, so that justice can be realized. John Rowls in his book A Theory of Justice explains the relationship between natural law and positive law. For Rawls, the binding power of positive law (Lex humana) is based on natural law (Lex natura) which is based on fairness values. These values of justice require the existence of togetherness which is the desire of all human beings. This is what is meant as social justice which must be incarnated in the wider community (Soetiknjo, 2005).

\subsection{State Sovereignty, Defense Aspects of Land} Control by Foreigners Against the Outermost Small Islands which indicate the existence of a Sale and Purchase

\section{Agreement}

In order to increase opinion through foreign exchange, Indonesia is competing with various countries to create legal instruments for the welfare of the people by giving permission for the international community, especially investors to invest directly in Indonesia, either in the form of leasing or public private ownership. This also invites fresh air from both the government itself and foreign investors in Indonesia coupled with the geographical location of the strategic region, namely between the Asian continents and the Australian continent and between the
Pacific Ocean and the Indian Ocean while in Indonesia itself consists of unique coastal areas with $70 \%$ The waters and land use in the form of various islands, as well as qualified natural resources both on land and at sea make Indonesia one of the countries that are highly targeted by foreign investors to invest. In addition, Indonesia itself is a country that has fairly good ease of doing business. As for the rights obtained by foreigners, it is regulated in the following series:

1. PP 103 of 2015 concerning the ownership of residential/residential houses for foreigners;

2. PP 40 of 1996 concerning Cultivation Rights, Building Use Rights and Land Use Rights;

3. UU no. 5 of 1960 concerning Basic Agrarian Regulations, etc.

By law, many foreign investors have met the requirements for permits for residence, business or vacation. Unfortunately, there are several indications of violations regarding foreigners and domestic investors who are even more sad to be involved in it and the community itself, where there are buying and selling of land related to foreigners in the unitary territory of the Republic of Indonesia in the form of small islands and coastal areas of Indonesia, tempted by the beauty the natural surroundings sometimes don't sometimes make anyone fall in love. The issue of buying and selling this island has spread since the end of the New Order regime which was replaced by the era of democracy. This is of course closely related to the poverty level of the community, sometimes making there are naughty elements who sell the Sipadan area or the small outermost island of Indonesia. what makes it sad is that sometimes the government sometimes seems slow in handling this matter even though it is also related to aspects of state defense and security which has violated the principle of state life.

Indonesia is one of the largest archipelagic countries in Asia with a vast area that includes maritime and ocean expanses as well as natural resources in it, Indonesia is known to be very rich in addition to its natural resources, Indonesia is also considered to have productive and superior human resources and is quite superior in Indonesia. area is about 70\%. Geographically, Indonesia is a country with a tropical climate, while the number of islands in Indonesia is 17,508 islands. First, "The total area of Indonesia is 7.81 million $\mathrm{km} 2$, which consists of 2.01 million $\mathrm{km} 2$ of land, 3.25 million $\mathrm{km} 2$ of ocean, and 2.55 million $\mathrm{km} 2$ of the Exclusive Economic Zone (EEZ)", so Indonesia deserves the title of the largest archipelagic country. in this world (Septiadi, 2017). The number of islands in Indonesia is a blessing from God Almighty, in the form of natural resources, to be controlled by the Indonesian people which are used for the full benefit of all 
Indonesian people, by present and future generations.Second, Specifically, the sustainable management of marine resources is aimed at improving the welfare of the Indonesian people (Amiek, et al., 2019). one of the largest sources of the economy in Indonesia, not a few who depend on the catch from local fishermen. It is said that because if the total area of Indonesia is calculated, it is about $70 \%$ of the water area and the rest is archipelago (Pratikto, 2003).

Based on the juridical analysis of the regulations above, it is known that the determination of the area to be designated as Special Economic Zone (SEZ) must meet 4 (four) criteria. The first criterion, "SEZ must be in accordance with the Regional Spatial Plan and not have the potential to disturb the Protected Area". There are three (3) types of Regional Spatial Planning (RTRW) based on their level, namely: National RTRW, Provincial RTRW, and Regency/City RTRW, which must be integrated with one another. The Government of the Republic of Indonesia Number 26 of 2008 concerning the National Spatial Plan is a policy direction and strategy for the use of state territory space". Regarding the Provincial RTRW and Regency/City RTRW, they are prepared by adjusting the characteristics of each region but must refer to the National RTRW. In addition to being in accordance with the RTRW, the determination of the SEZ area must also not interfere with the Protected Area. Based on the explanation of Article 4 letter a, of the Law on Special Economic Zones, "Protected Areas are areas designated with the main function of protecting environmental sustainability which includes natural resources and artificial resources".

The government certainly has the authority in terms of maintaining, supervising, developing and using natural resources anywhere that are included in the territory of the Republic of Indonesia for the prosperity of the people as the essence of Article 33 of the Constitution of the Republic of Indonesia, then with the task of authority given by the constitution alias rights of every Indonesian citizen., then the government formed a study of the Establishment of Special Economic Zones for Small and Outermost Islands (SEZ-PKT) plan, this plan was then implemented by the legislation on special economic zones.

1. Law Number 39 of 2009 concerning Special Economic Zones, Presidential Regulation of the Republic of Indonesia Number 33 of 2010 concerning the National Council and National Council for Special Economic Zones;

2. Government Regulation Number 2 of 2011 concerning the Implementation of Special Economic Zones;

3. Presidential Regulation of the Republic of Indonesia Number 33 of 2010 concerning the National Council and National Council of Special Economic Zones, Presidential Regulation of the Republic of Indonesia Number 124 of 2012 concerning Amendments to Presidential Regulation Number 33 of 2010 concerning the National Council and Council for Special Economic Zones;

4. Coordinating Minister for the Economy Regulation Number 7 of 2011 concerning Guidelines for Proposing the Establishment of Special Economic Zones.

In addition to the economic crush, there are rogue elements, both from the community or claiming to be coastal communities, and then being tempted by the lure of the sale of land from foreign parties, which causes not a few from coastal areas, especially small and outer islands to make guile to then trade land or small islands. the outermost and outermost areas to meet the needs of a personal interest without looking at the environmental aspects and the legal impact of the sale and purchase agreement of the outermost small island land by the surrounding population. As for usually the sale and purchase is categorized into a nominee agreement. this is not only a community problem but also the government as a representative of the people has the task of maintaining people's sovereignty through the misuse of land and islands in remote and outermost areas itself, further complicated issues and have not been resolved to date due to limited infrastructure and facilities to provide guidance, supervision, and development especially for islands that are remote, difficult to reach and uninhabited, the size of the islands on the border are generally very small islands that are very vulnerable to damage both by nature and humans, not yet synchronized border management, including institutional, programs, as well as clarity of authority, the absence of clear and comprehensive laws and regulations in the management of PKT, misinterpretation of the Law on Regional Government which causes various conflicts in the authority of the management of water areas, lack of socialization $\mathrm{i}$ about the existence and importance of the outer islands (Adiyanto, et al., 2007).

The Ministry of Maritime Affairs and Fisheries conveyed a number of land problems that occurred in the small islands of Indonesia. Minister of Maritime Affairs and Fisheries, Susi Pudjiastuti, said her agency was reorganizing the management and utilization of small islands for the greatest prosperity of the people. The following are problems that often occur on small islands:

1) State defense and security, especially in small and outermost islands (PPKT).

2) Sale of land or small islands to foreign nationals, for example Maratua Island in Berau Regency. 

Indonesians, such as Nikoi Island in Tanjung Pinang, Bawah Island in Anambas, and Manis Island in Batam City.

4) The use of nominees (name borrowing agreements) in land tenure and investment processes, as happened on Maratua Island, Berau Regency, and Bidadari Island, Labuan Bajo.

5) The issue of occupancy or claims of island ownership by citizens of other countries, as happened in Pulau Manis, Batam City.

6) Environmental damage and pollution on small islands, such as Bangka Island in North Minahasa and small islands in Bangka Belitung Province.

7) Closure of access to local communities and fishermen by investors in small islands, such as Gili Gede, in West Lombok, Nikoi Island in Tanjung Pinang, and several islands in Wakatobi. 8) Conflicts over land use and forest conversion between investors and communities, such as on Romang Island in Southwest Maluku Island, Pari Island in the Thousand Islands, and Jemaja Island in the Anambas Islands.

9) Illegal activities on small islands, such as smuggling of people and goods, slavery, illegal fishing, illegal logging, drugs, such as on Benjina Island in the Aru Islands Regency and Bawah Island in the Anambas Islands.

10) Violation of land regulations, granting individual land rights (SHM) which reaches 20 hectares per person in one stretch, such as Maratua Island in Berau. Utilization of small islands has not provided optimal PNBP for the state. (Budiyanto, 2017).

11) The President himself has issued a Decree on the list of geographical coordinates of the bases of the Indonesian archipelago, which was later abbreviated as this Presidential Decree. Based on Presidential Decree 38 of 2002 concerning the List of Geographical Coordinates of the Baselines of the Indonesian Archipelago, as amended by Government Regulation No. 37 of 2008, there has been a change in the number of islands. the outermost small island, making it 111 (one hundred and eleven) Outermost Islands, President Joko Widodo signed Presidential Decree number 6 of 2017 concerning the Designation of the Outermost Islands. Which Outer Islands have white sandy beaches and are very exotic, so they are in great demand both as tourism destinations and until then, they are sought after by foreigners in various ways; either by "purchasing" the individual owners of the land with the right of ownership on the island, the question is, how come the island bordering the high seas can be issued a certificate even though the stipulations that govern it are clear, Article 60 and Article 62 of PP 40 of 1996. As has been explained regarding the procedure defects in the ownership of land tenure above where foreigners become landlords while the rogue person becomes the object of power over the foreigners themselves, in fact Certificates are still issued by the local land office/land office. Do they not know, do not understand or pretend not to understand? Because after being controlled by foreigners, many problems arise.

In essence, small islands may not be owned by foreigners or foreign legal entities. If a foreign party wishes to exploit a small island and the surrounding waters for the purpose of foreign investment, it must obtain a permit from the Minister. Foreign investment must prioritize the national interest (Hasanah, 2017). If this is the case, the 11 points above must be the attention of the Ministry of KKP and should be of no small concern to the Coordinating Minister for Political and Security Affairs; not only at the level of rules on paper, but implementation and strict supervision in the field, and if there is a clear violation, action must be taken, moreover it will endanger the country's resilience. In terms of what can be dangerous/there is a claim to the island in Riau by Malaysia, and has happened with the loss of the island of Sigitan. The sale of the island in Labuan Bajo, the control of the island in the Gilis, either sold under the name of a local person or controlled through a long lease. If so, where is the Nationalism of PPAT's fellow Notaries for making such a model deed and the supervisory body for land control by foreigners.

\section{Conclusions}

As an Indonesian nation, the purpose of managing coastal resources and small islands in Article 22 paragraph (2) of Law Number 32 of 2014 and also Article 4 of Law Number 27 of 2007 should be implemented more into practice, not only expecting implementation from the government, but as a community we also take part in the management so that these goals can be realized, also for the good and progress of the Indonesian maritime sector.

Besides that, the government must take a stand in correcting deficiencies in its regulation, not only that the community must also be given counseling on policies that have been issued by the government and its regulations regarding land tenure on the outermost and remote islands, on how to manage, supervise and use the surrounding land so that it does not cause the occurrence of the agreement which is legally called illegal. Full attention is expected for the author to the government in coordination with the local council representatives. This aside from providing information on issues in the field of resilience, the government also pays more attention to legal, economic, political and cultural issues for the welfare of the local people. to avoid the recurrence of related issues where the community gives ownership of their land to foreigners because the value of the foreigners themselves are high.

Legal arrangements for ownership and control of land need to be realized immediately as an integrated ecosystem with the 
surrounding waters, in the form of separate laws and regulations by taking into account economic, political, socio-cultural, environmental and defense and security aspects in an integrated manner. Besides that, it is also technical in the field, if the law allows the control of the outermost and marginalized island lands which must be considered carefully how to make such a deed and supervision of institutions related to the existence of arrangements that in the future provide legality to foreigners who want to own the outermost island land. Few of the authors said that if this happened, there would certainly be discrimination against indigenous people in the area because the status of the community's own rights is no longer prioritized or special and seems to deviate far from the management, supervision and use of rejuvenation for the surrounding environment because it is possible that the indigenous people are increasingly being marginalized. will be excluded. Related to the resilience and security of the state, it becomes the last focus for the government in protecting the internal security and resilience of the outermost and remote islands against the interests and objectives of advancing the Republic of Indonesia.

\section{References}

1. Adiyanto, E., Eidman, E., Adrianto, L. (2007). Tinjauan Hukum dan Kebijakan Pengelolaan PulauPulau Kecil Terluar Indonesia (Studi Kasus Pulau Nipa. Buletin Ekonomi Perikanan, 7(2), 51-62. Available at http://journal.ipb.ac.id/index.php/bulekokan/article/vi $\underline{\text { ew/2654/1637 }}$

2. Amiek, S., Indarti, E., Pujiyono, Diamantina, A. (2019). Konsep Negara Kepulauan Dalam Upaya Perlindungan Wilayah Pengelolaan Perikanan Indonesia. Jurnal Masalah-Masalah Hukum, 48(3), 241-248.

https://doi.org./10.14710/mmh.48.3.2019.241-248

3. Arisaputra, M.I. (2015). Penguasaan Tanah Atas Pantai dan Wilayah Pesisir di Indonesia. Perspektif Hukum, 15(1), 27-44. Available at https://disperkim.samarindakota.go.id/asset/filelib/ad s/22-34-1-PB.pdf

4. Budiyanto, B. (2017). Kebijakan Dan Implementasi Pendayagunaan Pesisir Dan Pulau-Pulau Kecil.

Available at http://kkp.go.id/an-

component/media/upload-gambarpendukung/djprl/HUMAS/Kebijakan\%20dan\%20Im plementasi\%20Pengelolaan\%20dan\%20Pendayagun aan\%20P3K\%20Edit.pdf , accessed on June 1, 2020.

5. Chimawati, N.F. (2020). Pengelolaan Wilayah Pesisir Dan Pulau-Pulau Kecil Di Indonesia (Dalam Perspektif Perlindungan Hukum bagi Hak-hak
Ekonomi Masyarakat Tradisional). Jurnal Hukum, 4(2), 396-417.

6. Diantha, I M. P. (2015). Metodologi Penelitian Hukum Normatif dalam Justifikasi Teori Hukum. Denpasar, Kencana Prenadamedia Group.

7. Efendi, J. and Ibrahim, J. (2016). Metode Penelitian Hukum Normatif dan Empiris. Depok, Prenadamedia Group.

8. Elysia, V. (2014). Kajian Pengelolaan Wilayah Pesisir dan Pulau-Pulau Kecil di Kabupaten Kaimana, Papua Barat. Forum Ilmiah, 11(3), 334343. Available at https://ejurnal.esaunggul.ac.id/index.php/Formil/artic le/view/1082/995

9. Hikmahanto. (2017). Hukum Tanah Nasional: Sejarah, Politik, dan Perkembangannya. Jakarta, UNUSIA Press.

10. Fuadi, M. (2013). Teori-Teori Besar (Grand Theory) Dalam Hukum. Jakarta, Kencana Prennamdeia Group.

11. Hasanah, S. (2017). Bolehkah Pulau-Pulau Kecil diberikan Hak atas Tanah?, Availabe at https://m.hukumonline.com/klinik/detail/ulasan/lt58a cfa5997514/bolehkah-pulau-pulau-kecil-diberikanhak-atas-tanah, accessed on June 30, 2021.

12. Pratikto, W.A. (2003). Kebijakan Penataan Pesisir dan Pulau-Pulau Kecil di Indonesia. Alami, 8(3), 1-7. Available at https://media.neliti.com/media/publications/195590ID-kebijakan-penataan-pesisir-dan-pulau-pul.pdf

13. Pound, R. (1997). Social Control Through Law, New Jersey: New Brunswick.

14. Ranto, R. (2017).Kajian Yuridis Hak Atas Tanah Reklamasi Menurut Undang-Undang Nomor 27 Tahun 2007 Juncto Undang-Undang Nomor 1 Tahun 2014 Tentang Pengelolaan Wilayah Pesisir Dan Pulau- Pulau Kecil. Lex Privatum, 5(3), 22-28.

15. Rasjidi, L. \& Rasjidi, I. T. (2007). Dasar-dasar Filsafat dan Teori Hukum. Bandung: Citra Aditya Bakti.

16. Saptiadi, I.M. (2017). Kajian Tentang Penguasaan Tanah Pantai dan Wilayah Pesisir Di Indonesia. Jurnal Teknologi, 16(2), 2122-2130.

17. Soetiknjo. I. (2005). Politik Agraria Nasional. Yogyakarta, Penerbit Gadjah Mada University Press.

18. Subagyo, A., Wijayanti, W.P., Zakiyah, D.M. (2017). Pengelolaan Wilayah Pesisir dan Pulau-pulau Kecil. Malang, UB Press.

19. Ulisah. (2017). Tujuan Pengelolaan Sumber Daya Pesisir dan Pulau-pulau Kecil Dalam Pasal 4 
Undangundang Nomor 27 Tahun 2007 Tentang

Pengelolaan Wilayah Pesisir dan Pulau-pulau Kecil

Serta Pasal 22 Ayat (2) Undang-undang Nomor 32

Tahun 2014 Tentang Kelautan, Gema Keadilan, vol.

4, no. 1, pp. 13-23.

https://doi.org/10.14710/gk.4.1.13-23

20. Waluyo, A. (2013). Permodelan Pengelolaan

Wilayah Pesisir Dan Pulau-Pulau Kecil Secara

Terpadu Yang Berbasis Masyarakat (Studi Kasus

Pulau Raas Kabupaten Sumenep Madura). Jurnal

Kelautan, 6(1), 74-88. Available at

https://journal.trunojoyo.ac.id/jurnalkelautan/article/v

iew/835/734

Law and Regulations

21. Indonesia, The Constitution of the Republic of Indonesia

22. Indonesia, Basic Agrarian Law No. 5 of 1960 (Supplement to the State Gazette Number 2043)

23. Indonesia, Law Number 23 of 2014 concerning Regional Government

24. Indonesia, Law Number 27 of 2007 concerning Management of Coastal Areas and Small Islands (PWP3K), as amended

25. Indonesia, Law Number 1 of 2014, states the definition and limitations of the PWP3K law.

26. Indonesia, Government Regulation 40 of 1996 concerning Cultivation Rights, Building Use Rights and Land Use Rights (Supplement to the State Gazette of the Republic of Indonesia 1996 Number 3643)

27. Indonesia, Presidential Regulation of the Republic of Indonesia Number 10 of 2006 concerning the Organizational Structure of the National Land Agency

28. Indonesia, Decree of the President of the Republic of Indonesia Number 38 of 2000 concerning the Establishment of a National Independent Investigation Team for the Maluku Conflict. 